\title{
The Response of Sobaity Sea Bream Sparidentex hasta Larvae to the Toxicity of Dispersed and Undispersed Oil
}

\author{
Qusaie Karam ${ }^{1 *}$, Neila Annabi-Trabelsi ${ }^{2}$, Sabeekah Al-Nuaimi ${ }^{1}$, Mohammad Ali ${ }^{1}$, \\ Khaled Al-Abdul-Elah ${ }^{1}$, Mirza Umair Beg ${ }^{1}$, Matt Bentley ${ }^{3,4}$
}

\author{
${ }^{1}$ Environment and Life Sciences Research Center, Kuwait Institute for Scientific Research, \\ P.O. Box 24885,13109 Safat, Kuwait \\ ${ }^{2}$ Laboratoire Biodiversité Marine et Environnement (LR18ES30), Universite' de Sfax, \\ Route Soukra Km 3.5, B.P. 1171, CP 3000 Sfax, Tunisia \\ ${ }^{3}$ Dove Marine Laboratory, School of Marine Science and Technology, Newcastle University, \\ Newcastle upon Tyne, NE1 7RU, United Kingdom \\ ${ }^{4}$ Newcastle University, Singapore, 567 739, Singapore
}

Received: 27 October 2020

Accepted: 11 February 2021

\begin{abstract}
Accidental oil spillages can release millions of barrels of oil into the marine environment threatening aquatic wildlife like fisheries. As a part of the oil spill response strategy, several chemical dispersants have been recommended that have been successfully used elsewhere. However, the adverse effects of dispersed oil are unknown to fish species in Kuwait. Therefore, this study investigated the toxicity of water-accommodated fraction (WAF) and chemically enhanced water-accommodated fraction (CEWAF) of Kuwait crude oil (KCO) with three dispersants (Corexit ${ }^{\circledR}$ 9500, Corexit ${ }^{\circledR}$ 9527, and Slickgone ${ }^{\circledR}$ NS) against the larvae of the sobaity sea bream Sparidentex hasta which is of an international economic significance. Total petroleum hydrocarbons (TPH) were used for comparison of chemical compounds partitioned in WAF of dispersed and non-dispersed oil. Toxicity test results with fish larvae showed that WAF of non-dispersed oil and Corexit ${ }^{\circledR} 9527$ treated CEWAF had similar $\mathrm{LC}_{50}$ values $\left(0.12 \mathrm{~g}\right.$ oil. $\left.{ }^{-1}\right)$ whereas CEWAF's of Corexit ${ }^{\circledR} 9500$ and Slickgone ${ }^{\circledR}$ NS CEWAF showed lower toxicity.
\end{abstract}

Keywords: oil dispersants, fish toxicity test, $\mathrm{PAH}, \mathrm{LC}_{50}$, sea bream

*e-mail: qusaiekaram99@gmail.com 


\section{Introduction}

The increasing global demand for energy, led to increased exploration and extraction of oil from various regions of the world, specifically in the offshore environments [1-3]. As crude oil and related petroleum products are transported across global regions by ships or pipelines, accidental oil spillages can occur, leading to devastating environmental crises with a chronic toxic effect on marine organisms like fish [4-8]. Oil spill accidents like 1989 Exxon Valdez, Arabian Gulf oil spill, and 2010 Deepwater Horizon have resulted in severe adverse effects on marine organisms. Also, major concerns have been raised regarding the chronic toxicity of dispersant usage as response agents in future oil spills in various marine environments ranging from tropical to polar and the multitude of hazards associated with it [9-12].

The Arabian Gulf region has experienced small to massive oil spills through natural seepage, war-related activities, accidents of tankers, and offshore drilling [13, 14]. The Regional Organization for the Protection of the Marine Environment (ROPME) in the Arabian Gulf adopted an oil spill response strategy and recommended a list of dispersants to be used in the ROPME Sea Area in the case of an oil spill [15-17]. Spilled oil floats on the surface due to its low density and forms a thin layer that spreads on the water surface [18]. Wave action breaks the oil slick into $\geq 100 \mu \mathrm{m}$ oil droplets that disperse in the water column. Chemical dispersants facilitate the dispersion of oil as small oil droplets $(10-50 \mu \mathrm{m})$ by lowering the interfacial tension between oil and water. Thereby, its impact is reduced on surfacedwelling marine organisms' like fish larvae, marine mammals, and sea birds [19, 20]. However, some tradeoffs reflect the complexity of dispersants applications as it facilitates the entrance of oil in the water column, thus rendering it hazardous to benthic biota [21].

There are numerous concerns about the toxic effect of dispersed oil on fish, which live in the water column [22-27]. The fraction of oil that is partitioned in the water phase is termed as water accommodated fraction (WAF) and routinely measured as total hydrocarbons (THC). In the field experiments during an oil spill, the THC concentrations below the oil slick after dispersant treatment ranged from 30-50 mg. $\mathrm{l}^{-1}$ which eventually decreases after few hours to $<1-10 \mathrm{mg}^{-1} \mathrm{1}^{-1}$ $[20,28]$. The THC fraction is bioavailable to the marine organism and its effects have been earlier studied and several concerns have been raised on the application of chemical dispersants to disperse oil slicks after the Deep Water Horizon (DWH) oil spill incident in the Gulf of Mexico in 2010 [29-32]. It is imperative to highlight that both Corexit ${ }^{\circledR} 9500$ and 9527 chemical dispersants were used in the Deep Water Horizon (DWH) oil spill in the Gulf of Mexico in 2010 to combat surface and subsurface oil spillages. However, the consequences of using large volumes of oil dispersants during the DWH are unknown [33] as there are indications for Corexit 9527 and 9500 being toxic to marine life [34].

The objective of this study is to expand the knowledge on the toxicity of dispersed and undispersed oil to the larval stage of marine fish species (Sobaity Sea bream $S$. hasta) which is considered of global significance to fisheries. The current study has three main folds: (1) provide information on the analytical method to assess oil toxicity and oil spill combat products (Corexit 9500, 9527 and Slickgone) on marine fish, (2) provide approximate toxicity data that can be used for hazards assessment in marine pollution scenarios, and (3) support global toxicity database of hazards chemicals to the marine ecosystem. The bulk of acute toxicity data generated in the literature concerning oil and dispersed oil encompassed two oil dispersants of the Corexit formulation. Nevertheless, to our knowledge, not much work focused on investigating their acute toxic effect in combination with Kuwait crude oil (KCO) on Sobaity Sea bream S. hasta. The authors aims that the outcomes of this study will be helpful to utilize Sobaity Sea bream S. hasta as indicator species for oil contamination.

\section{Literature Review}

In literature, few studies have investigated the toxic effects of dispersed and undispersed Kuwait crude oil (KCO) on marine fish. Also, sea bream fish was not the subject of much ecotoxicological research that assesses the adverse effects of hazardous chemicals threatening marine ecosystems. Others like [35] investigated the effects of water-soluble fractions of Iraq crude oil on larval and post-larval stages of gilthead sea bream (Sparus aurata). Also, the effects of water-soluble fractions of $\mathrm{KCO}$ on growth, bioactivity, and survival of larval stages of red sea bream (Pagrus major) and black sea bream (Acanthopagrus schlegeli) were examined by [36]. Also, it's been demonstrated that exposure of fish like tilapia, African catfish, and carp to water-soluble fractions (WSF) of crude oil can affect its hematological characteristics [37-40]. And, juvenile African sharptooth catfish C. gariepinus exposed to sublethal levels of WSF affected its growth performance [39]. Moreover, northern wolfish Anarhichas denticulatus exposed to mechanically, chemically dispersed oil and dispersant for $48 \mathrm{hrs}$ resulted in reducing acetylcholine (Ache) activity in its brain as it is an integral nervous system function [25, 41]. Juvenile turbot (Scophthalmus maximus) exposed to fuel oil and/ or Finasol OSR 52 chemical dispersant resulted in an additive effect of oil contamination coupled with hydrostatic pressure on turbot cellular oxygen consumption. This combination reduced $S$. maximus capacity to withstand high pressure $(10.1 \mathrm{MPa})$ after being contaminated with either test chemicals [42]. Also, exposure to sublethal concentrations of oil can exhibit an array of adverse effects in the early life stages of marine fish such as 
larval behavioural impairment, CYPA1 induction but not AChE inhibition [4, 43].

In the present study, Kuwait crude oil (KCO) in different thicknesses was layered over the fixed surface area and volume of seawater to prepare WAF. Selection of fish early life stages in this study because this stage tends to be the most sensitive to crude oil exposure and comparisons of toxicity results among test species and their life stages [44-47]. Fish in its early life stage showed sensitivity to oil-derived polycyclic aromatic hydrocarbons (PAHs) which eventually lead to significant impacts of a series of ecological effects like fish population survival and recruitment [48-51]. The selection of early life stages like the embryonic stage in haddock fish has concluded that it's more vulnerable to crude oil toxicity than larval stages $[52,53]$. As there is a lack of knowledge regarding the toxic effects of dispersed and undispersed oil specifically to fish species indigenous to the Arabian Gulf, careful toxicological assessment can help in oil spill response and mitigation.

This study will provide information on whether the application of chemical dispersants to oil will enhance its acute toxicity or not and also indicate the amount of oil on the surface detrimental to fish larvae survival. The data will be useful in deciding by the regulatory authorities about the use of dispersant in case the oil spill occurs during the breeding season of fish. The objective of the study herein is to assess the toxicity of dispersed and undispersed $\mathrm{KCO}$ and dispersed $\mathrm{KCO}$ with individual oil dispersants like Corexit ${ }^{\circledR}$ EC 9500A and Corexit ${ }^{\circledR}$ EC 9527A Slickgone ${ }^{\circledR}$ NS on larvae of marine sobaity sea bream fish Sparidentex hasta.

\section{Material and Methods}

\section{List of Abbreviations}

Several abbreviations have been used in this study which are listed in Table 1.

\section{Preparation of WAF and CEWAF}

Kuwait Export Crude Oil (API-3.18) was stored in $21^{-1}$ amber bottle with no headspace at room temperature $\left(26^{\circ} \mathrm{C}\right)$ in a dark place. The technical specifications for the oil are: gravity (30.18), density (0.8744 G.ml at $\left.15^{\circ} \mathrm{C}\right)$, sulfur content $(2.6 \%$ weight), viscosity $\left(17.38 \mathrm{cSt}\right.$ at $\left.20^{\circ} \mathrm{C}\right)$, total nitrogen $(0.15 \%$ weight $)$, Reid vapor pressure $(8.16 \mathrm{Psi})$, pour point $\left(-25^{\circ} \mathrm{C}\right)$, water content $(0.004 \%$ weight), and Conradson Carbon Residue (CCR- 6.2\% weight). Chemical dispersants investigated were Corexit $^{\circledR}$ EC 9500A and Corexit ${ }^{\circledR}$ EC 9527A (Onedo Nalco Ltd. 2005), United Kingdom (Local agent Bobyan Shipping \& Marine Services), and Slickgone ${ }^{\circledR}$ NS (the Dasic United Kingdom, 2007, local agent Middle East Chemical Manufacturing Co.). Natural seawater was collected and filtered through $0.45 \mu \mathrm{m}$ Whatman ${ }^{\circledR}$ sterile membrane filter paper for the preparation of water accommodated fraction and chemically enhanced water accommodated fraction, and the same water was used for further dilutions. WAF of $\mathrm{KCO}$ was prepared at $1,10,20,40$, and $80 \mathrm{~g}$ oil. $\mathrm{1}^{-1}$ seawater in pre standardized conditions, according to [54].

For the preparation of CEWAF, a fixed oil loading of $1 \mathrm{~g} \mathrm{KCO}^{-1}$ filtered seawater $\left(2 \mathrm{~g} \mathrm{KCO} / 2 \mathrm{l}^{-1}\right.$ seawater) was selected for the preparation of water-accommodated fraction (WAF) and a 10:1 (oil: dispersant) ratio where $0.1 \mathrm{~g}$ oil dispersant $\left(0.2 \mathrm{~g}\right.$ oil dispersant per $2 \mathrm{l}^{-1}$ seawater) was used and layered over the oil slick in a 21 glass aspirator bottle filled with $21 \mathrm{l}^{-1}$ of seawater for the chemically enhanced water-accommodated fraction (CEWAF) preparations [44]. The test chemical was mixed for $24 \mathrm{hrs}$ then stopped, and the solution was left to stand for $3 \mathrm{hrs}$ for a complete phase (oil/water) separation. The solutions of WAF/CEWAF were drained, collected in amber bottles, and preserved in a refrigerator until the experiments take place [55].

\section{Chemical Characterization}

Analysis of total petroleum hydrocarbons (TPH); $100 \mathrm{l}^{-1}$ of WAF/CEWAF sample solution was extracted by adding MERCK ${ }^{\circledR}$ dichloromethane $\left(\mathrm{CH}_{2} \mathrm{Cl}_{2}\right)$ in a solvent-rinsed 2 separatory funnel with Teflon stopcock and stopper. The mixture was shaken vigorously and dried over MERCK ${ }^{\circledR}$ grade anhydrous sodium sulfate $\left(\mathrm{Na}_{2} \mathrm{SO}_{4}\right)$ and glass wool, which were presoaked and rinsed with dichloromethane then the solvent layer was collected in a volumetric flask, which was labeled and stored for later analysis. The collected extract was then analyzed on an RF-5301 PC SHIMADZU® Spectrofluorophotometer instrument using $310 \mathrm{~nm}$ excitation and $360 \mathrm{~nm}$ emission wavelengths. A standard multipoint calibration curve for TPH analysis was prepared using Kuwait crude oil and was reported in terms of the $\mathrm{KCO}$ equivalents [56].

\section{Larval Rearing}

Larval stages of $S$. hasta were obtained from the hatchery of the Aquaculture Program at Kuwait Institute for Scientific Research, 24 hrs after hatching (Fig. 1). Stocking density in rearing tanks for newly hatched larvae was 40 larvae per liter (1 liter was used), according to [57]. Rearing tanks were aerated with six air stones (5 x $5 \times 7$ each) and illuminated by sunlight and fluorescent light (40W) with 1500 lux light intensity at the water surface at noon and 1000 lux at night [58]. Water quality parameters for the fish holding water were: dissolved oxygen (5-6 mg. $\left.\mathrm{l}^{-1}\right)$, temperature $\left(20-28^{\circ} \mathrm{C}\right)$, salinity (40-42 ppt), and $\mathrm{pH}$ (8.2-8.6) (Fig. 2).

\section{Fish Exposure System}

$96 \mathrm{hrs}$ acute toxicity tests were conducted following the OCED (Organization of Economic Co-Operation 
Table 1 List of abbreviations used in this study for chemicals, statistics, measuring units, organizations, and countries.

\begin{tabular}{|c|c|}
\hline API & American Petroleum Institute \\
\hline CEWAF & Chemically Enhanced Water-Accommodated Fraction \\
\hline $\mathrm{cSt}$ & Centistokes \\
\hline${ }^{\circ} \mathrm{C}$ & Celsius \\
\hline CCR & Conradson Carbon Residue \\
\hline C.I. & Confidence Interval \\
\hline CROSERF & The Chemical Response to Oil Spill Environmental Research Forum \\
\hline DWH & Deep Water Horizon \\
\hline EPA & Environment Protection Agency \\
\hline g & Gram \\
\hline GLM & General Linear Model \\
\hline $\mathrm{h}$ & Hours \\
\hline $\mathrm{KCO}$ & Kuwait Crude Oil \\
\hline $\mathrm{L}$ & Liter \\
\hline $\mathrm{LC}_{50}$ & Lethal Concentration affecting $50 \%$ of the population \\
\hline $\mathrm{mg} / \mathrm{L}=\mathrm{mg} \cdot 1^{-1}$ & Milligram per liter \\
\hline $\mathrm{Mm}$ & Micrometer \\
\hline MOOPAM & Manual of Oceanographic Observations and Pollutant Analysis Methods \\
\hline $\mathrm{NCP}$ & National Contingency Plan \\
\hline NRC & National Research Council \\
\hline OCED & Organization of Economic Co-Operation and Development \\
\hline$P$ & Test of significance \\
\hline PAHs & Polycyclic Aromatic Hydrocarbons \\
\hline ppt & Parts Per Thousand \\
\hline ROPME & Regional Organization for the Protection of the Marine Environment \\
\hline SE & Standard Error \\
\hline SD & Standard Deviation \\
\hline THC & Total Hydrocarbons \\
\hline TPH & Total Petroleum Hydrocarbons \\
\hline U.S. & United States \\
\hline $\mathrm{W}$ & Watt \\
\hline WSF & Water-Soluble Fraction \\
\hline \pm & The sample mean differs from the population mean \\
\hline
\end{tabular}

and Development) Guideline for the testing of chemicals - Fish Embryo Toxicity (FET) Test [59]. Toxicity test was conducted using sobaity sea bream Sparidentex hasta larvae which is one of the most significant commercial fish in the region, with significant economic value and a wide geographic distribution ranging from Arabian Gulf to the Oman Sea and the Western Indian Ocean [45].
Toxicity tests were conducted using the following preparations: Kuwait crude oil (KCO WAF), KCO + Corexist $^{\circledR} 9500$ dispersants (Corexist ${ }^{\circledR} 9500$ CEWAF), $\mathrm{KCO}+$ Corexist $^{\circledR} 9527$ (Corexist $^{\circledR} 9527$ CEWAF), and $\mathrm{KCO}+$ Slickgone $^{\circledR}$ dispersant (Slickgone ${ }^{\circledR}$ CEWAF). Solutions were prepared by two methods: variable oil loading, using a series of decreasing concentration of KCO, and by single loading and subsequent serial 
a) Air bladder

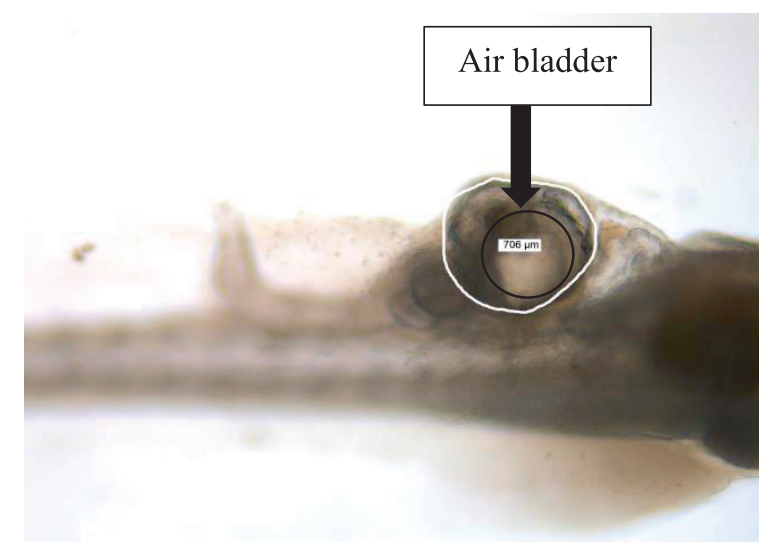

b) Gastrointestinal tract

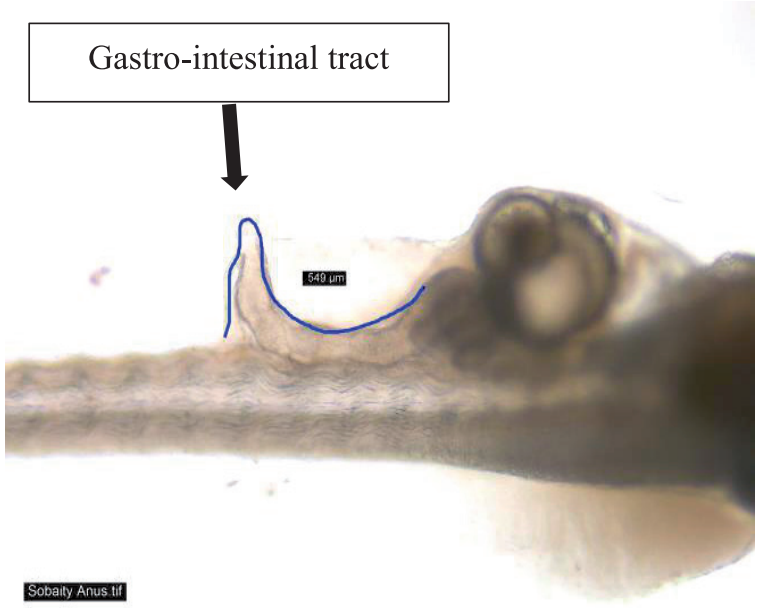

c)Heart

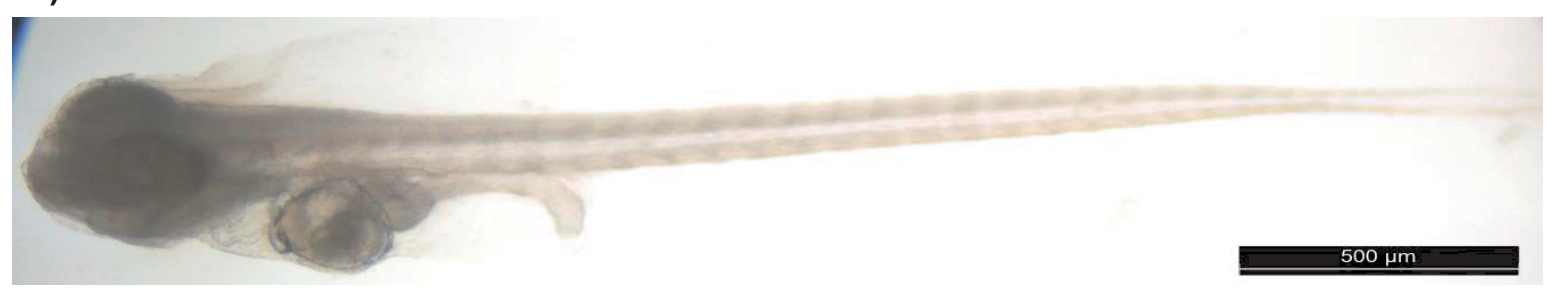

d) Eye

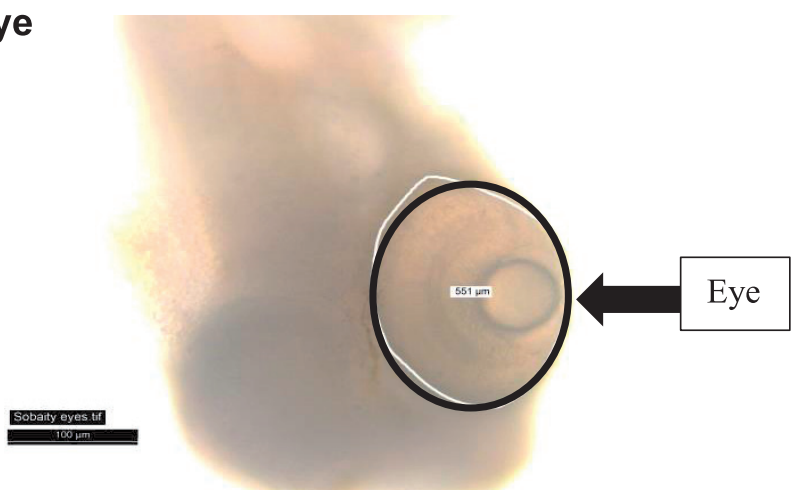

Fig. 1. Exhibit salient anatomical features of sobaity sea bream larvae. Photographed by Sabeekah Al-NuaimiC.

dilutions of $\mathrm{KCO}$ alone, and $\mathrm{KCO}+$ three individual oil dispersants in seawater according to CROSERF

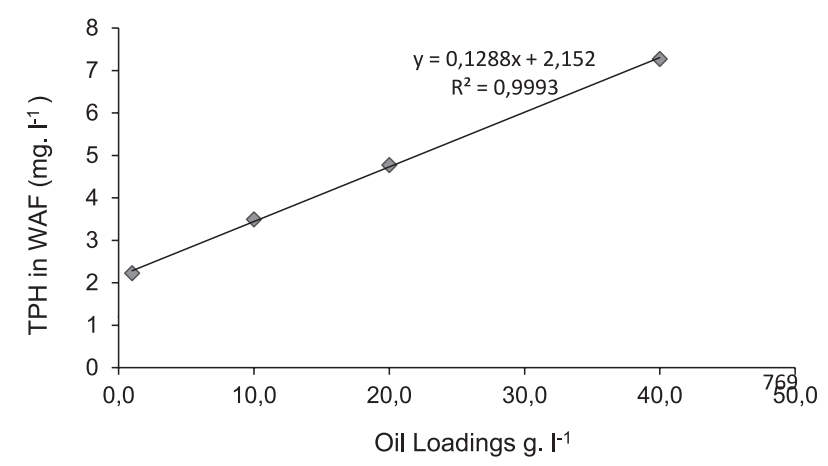

Fig. 2. Total polyaromatic hydrocarbons (TPH) concentration in water accommodated 773 fraction of Kuwait crude oil (KCO WAF) at different oil loadings to a fixed volume of water. protocols [60]. Filtered seawater was used to make variable loading of the WAF solution was obtained from the same holding tank that fish larvae were reared. Seawater was aerated with pure oxygen for 15 min until saturation before the bioassay. Five test concentrations of KCO WAF and KCO CEWAF plus a non-toxic control solution were prepared with an appropriate geometric dilution series selected in which each successive concentration is about $50 \%$ of the previous one such as $100 \%, 50 \%, 25 \%, 12.5 \%$, and $6.25 \%$. Static toxicity (non-renewal) test was conducted for 96 hrs with pre-hatched larvae. Fish larvae were not fed throughout the exposure period, and the main reason for not feeding the test organisms is that the yolk sac nourishes fish larvae for three days after hatching, and the oil globule further nourishes the same larvae for an additional two days. The initiation of toxicity was conducted $24 \mathrm{hrs}$ after hatching. The weight of larvae 
ranged between 0.10 and $0.75 \mathrm{mg}$. A minimum of 10 to 15 fish larvae was placed using a glass pasture pipette in $100 \mathrm{l}^{-1}$ glass beakers.

\section{Statistical Analysis}

All statistical analyses were conducted using Minitab $^{\circledR}$ Statistical Software -Version 17@ 2016 by Minitab Inc. General Linear Model (GLM) statistical approach was applied to the results in the study herein to test the effect of Kuwait crude oil (KCO WAF), KCO + Corexist $^{\circledR} 9500$ dispersants (Corexist ${ }^{\circledR} 9500$ CEWAF), $\mathrm{KCO}+$ Corexist $^{\circledR} 9527$ (Corexist $^{\circledR} 9527$ CEWAF), and $\mathrm{KCO}+$ Slickgone $^{\circledR}$ dispersant (Slickgone $^{\circledR}$ CEWAF) on $\mathrm{LC}_{50}$ for larval $S$. hasta. $P$ values were calculated, and effects were considered significant if $(p<0.05)$, and effects were considered not significant if $(p>0.05)$. Mean, standard deviation (SD), and standard error (SE) were calculated for biological experiments. Standard deviation was calculated to show how much variation there is from the mean, and standard error was calculated to show the extent to which the sample mean differs $( \pm$ ) from the population mean. $\mathrm{The} \mathrm{LC}_{50}$ value for each day of exposure was determined by Lethal Concentration Estimation Program Version 1.0, Copyright (C) 19901995, Institute for Inland Water Management and Waste Water Treatment RIZA (Lelystad, The Netherlands) and programmed by Modelco (Eindhoven, The Netherlands) by order of RIZA.

\section{Results and Discussion}

\section{Toxicity of Dispersed and Undispersed Oil}

There are numerous toxicity testing methods to investigate the adverse effects of oil and oil-related products on the marine ecosystem; particularly saltwater fish. In this study, we have adopted an exposure system of fish larvae to serial dilutions to low concentrations of a test chemical (KCO WAF/KCO CEWAF). It's imperative when interpreting toxicity data related to dispersed and undispersed oil to take into consideration the intricate and complex relationship between multiple factors like the physical/chemical composition of test chemicals, application procedures, exposures regimes, and environmental hazards $[11,61]$. As the concentration of dissolved petroleum hydrocarbons immediately following an oil spill event will particularly depend on several physical and environmental elements like seawater salinity, temperature, degradation by weathering and evaporation, and biological factors in the vicinity of the spillage area.

This study is amongst the few to investigate the toxic effects of dispersed and undispersed oil against $S$. hasta larvae. It is well established in marine pollution research that there are few standards test for fish to assess the toxicity of oil-related product like the use of inland silversides (Menidia beryllina) [62]. Even though some of the used fish species (saltwater/freshwater) like zebrafish and sheepshead minnow are considered tolerant to oil toxicity, but still they are being utilized due to the criteria for toxicity testing of oil product that they meet $[63,64]$.

Different types of dispersed and undispersed oil toxic effects on red sea bream ( $P$. major) have been investigated by others [65]. Chemical dispersant's manufacturer companies must submit a report highlighting the effectiveness of a chemical dispersant and its toxicity as a product to the United States Environment Protection Agency (U.S. EPA) to be listed in the National Contingency Plan (NCP) Product List [66]. Also, Corexit ${ }^{\circledR}$ chemical dispersant was listed to be used in the ROPME Sea Area, but its toxicity on native marine fish is not known. In this study, the selection of fish larval stages was justified on the basis that in oil spill scenarios, fish larvae will be vertically distributed in the water column and are likely to experience sporadic exposure to oil as water current carry them to contaminated areas [67]. Therefore, the selected chemical dispersant's toxicity was assessed in this study against marine fish early-life stages. In the study herein, recommended methods to use WAF/CEWAF for toxicity testing were followed because it is the soluble fraction that enters an aquatic environment with the most exceptional ease and as a result, can cause direct acute damage to aquatic organisms [68-70].

\section{Chemical Analysis of WAF Prepared at Variable Oil Loadings}

TPH concentration in WAF was $2.22,3.44,4.77$, 7.21, and $5.78 \mathrm{mg} . \mathrm{l}^{-1}$ for $1,10,20,40$, and $80 \mathrm{~g} . \mathrm{l}^{-1}$, respectively. The increase in TPH was linear up to $40 \mathrm{~g}^{-1} \mathrm{1}^{-1}$; however, the increase in TPH in WAF was not proportional to the oil loaded. Further, an increase in oil loading to $80 \mathrm{~g}^{-1} \mathrm{l}^{-1}$ resulted in the reduced partition of TPH in WAF than previous concentrations. The data for $80 \mathrm{~g}$. $\mathrm{l}^{-1} \mathrm{KCO}$ is not plotted in Fig. 3. This result was substantiated by studies on the chemical characterization of WAF reported, as others also encountered this difficulty in the preparation of WAF and concluded that oil to dissolving medium ratios did not increase the TPH content [20, 71-73]. [11] Observed that using a static exposure oil WAF tests revealed that hydrocarbons concentrations for TPH, (benzene, toluene, ethylbenzene, and xylene) BTEX and PAH were not constant showing a decline within $48 \mathrm{hrs}$.

\section{Toxicity of WAF Prepared at Variable Oil Loadings}

The toxicity of WAF prepared by varying oil loadings of $\mathrm{KCO}$ was determined in exposure chambers and fish larvae exposed for $96 \mathrm{hrs}$. Each WAF was prepared at 1, 10, 20, 40, 80 g. $1^{-1}$ were tested separately, and the exposure was run for $96 \mathrm{hrs}$. The data reported 


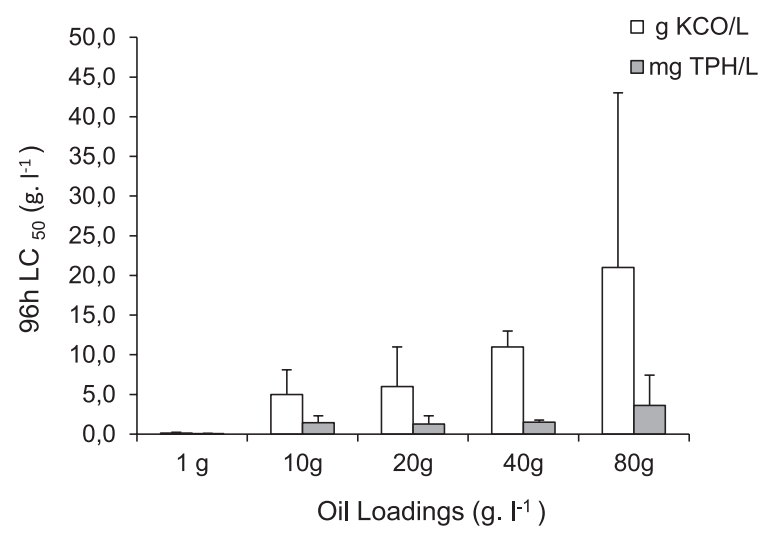

Fig. 3. Toxicity of water accommodated fraction of Kuwait crude oil (KCO WAF) prepared at different oil loadings showing $\mathrm{LC}_{50}$ values against $S$. hasta larvae after an exposure period of $96 \mathrm{hrs}$, expressed as g. $1^{-1}$ and mg. $1^{-1}$ for TPH. Error bars are standard deviations.

in Table 2 shows that exposure to WAF of 1 g. $1^{-1}$ seawater resulted in high $\mathrm{LC}_{50}$ values at $24 \mathrm{hrs}$, which decreased with the exposure time, and at $96 \mathrm{hrs}$, the averaged $\mathrm{LC}_{50}$ was $0.12 \pm 0.01 \mathrm{~g}$. $\mathrm{l}^{-1}$. It was interesting to note that WAF prepared at higher oil loading though contained higher TPH values but their toxicity was less than 1 g. $\mathrm{l}^{-1} \mathrm{KCO}$ concentration. The data in Table 2 shows that increasing oil loading could not increase the toxicity of WAF and the $\mathrm{LC}_{50}$ values obtained at 10, 20, 40, and 80 were 5.0 \pm 3.1 (C.I. 3.3-6.7); 6.0 \pm 3.19 (C.I. 3.3-6.70; $11.1 \pm 2.0$ (C.I. 7.1-17.4); $21.0 \pm 22.0$ (C.I. 12.3-27.1) g. $1^{-1}$ respectively (Fig. 4).

In the present study, $S$. hasta larvae exposed to the WAF prepared by various oil loadings and subsequent dilutions at nominal concentrations, which were not renewed every day (static exposure). It was observed that exposure concentrations decreased as time progressed from 0 to $96 \mathrm{hrs}$, which reflect the natural scenario in the marine environment as an oil spill undergo dilution and evaporation effects. When WAF prepared at different oil loadings (1-80 g. $\mathrm{l}^{-1}$ seawater) with subsequent serial dilutions of each loading separately, an interesting pattern emerged. The most toxic WAF's on sobaity sea bream larvae was found to be the one prepared at the lowest oil loading, i.e., 1 g. $~^{-1}$ seawater which was in agreement with what [46] observed that WAF solution was acutely lethal when prepared with only 0.01 to $0.1 \mathrm{~g} . \mathrm{l}^{-1}$ seawater applied oil loading. Except in the case of [74], the oil loading was even lower compared to the one used in this study. WAF prepared with increasing oil loadings ( $\geq 1$ g. $~^{-1}$ seawater) with serial dilutions was not found to exert increasing toxic effects indicating that saturation of water-soluble compounds was achieved at $1 \mathrm{~g}$. $\mathrm{l}^{-1}$ seawater oil loadings and a further increase in oil content could not increase the partitioning of water-soluble compounds in the aqueous medium. [11, 75] have indicated that crude oils have a limited narrow range of acute toxicity marine biota even though those oils might have a wide range of hydrocarbons content. Toxicity in oils is primarily caused by the presence of PAHs as major constituents of oils $[64,76]$ and more precisely the presence of naphthalene as oil drop emulsion is increased in WAF of oil [77]. It's imperative to mention too that when reviewing multiple oil toxicity studies in literature; a pattern of inconsistencies emerged indicating the difficulty and challenge in making comparisons between oil types and biological species investigated. [64] Suggested a universal analytical and exposure method in addition to side by side comparative studies between oils and test organisms.

\section{Chemical Analysis and Toxicity of CEWAF Prepared at Fixed Oil Loading}

WAF prepared at $1.0 \mathrm{~g} . \mathrm{l}^{-1}$ showed higher toxicity than at a higher concentration of oil on the surface of the water; therefore, chemical dispersants were applied at this oil loading. The application of dispersants caused an increase in TPH partitioned in CEWAF's.

Table 2. Showing different toxicity levels for all Kuwait crude oil water-accommodated fractions (KCO WAF) (g. $1^{-1}$ ) on $S$. hasta larval survival from 24 to $96 \mathrm{hrs}$, which was significant $(p<0.05)$ and as determined by the lethal concentrations which affects $50 \%$ of exposed larvae $\left(\mathrm{LC}_{50}\right)\left(\mathrm{g} . \mathrm{l}^{-1}\right)$.

\begin{tabular}{|c|c|c|c|c|c|c|}
\hline $\begin{array}{c}\text { Oil loadings } \\
\left(\mathrm{g} . \mathrm{l}^{-1}\right)\end{array}$ & $\begin{array}{c}\mathrm{LC}_{50}\left(\mathrm{~g}^{-1} \mathrm{l}^{-1}\right) \\
24 \mathrm{hrs} \pm \mathrm{SD}^{\mathrm{a}} / \mathrm{SE}^{\mathrm{b}}\end{array}$ & $\begin{array}{c}\mathrm{LC}_{50}\left(\mathrm{~g} . \mathrm{l}^{-1}\right) \\
48 \mathrm{hrs} \pm \mathrm{SD} / \mathrm{SE}\end{array}$ & $\begin{array}{c}\mathrm{LC}_{50}\left(\mathrm{~g} . \mathrm{l}^{-1} \mathrm{~L}\right) \\
\mathrm{hrs} \pm \mathrm{SD} / \mathrm{SE}\end{array}$ & $\begin{array}{c}\mathrm{LC}_{50}\left(\mathrm{~g} . \mathrm{l}^{-1}\right) \\
96 \mathrm{hrs} \pm \mathrm{SD} / \mathrm{SE}\end{array}$ & $\begin{array}{c}96 \mathrm{hrs}^{9} \% \\
\text { C.I. }^{\mathrm{c}}\end{array}$ & $P^{*}$ \\
\hline 1 & $58.0 \pm 103.0 / 34.3$ & $2.0 \pm 2.0 / 1.0$ & $0.4 \pm 0.1 / 0.02$ & $0.12 \pm 0.1 / 0.03$ & $0.1-0.2$ & $p<0.05$ \\
\hline 10 & $17.0 \pm 6.1 / 4.0$ & $14.0 \pm 2.3 / 1.3$ & $8.1 \pm 2.2 / 1.2$ & $5.0 \pm 3.1 / 2.0$ & $3.3-6.7$ & $p<0.05$ \\
\hline 20 & $77.4 \pm 95.0 / 55.0$ & $55.4 \pm 27.0 / 16.0$ & $14.0 \pm 2.0 / 1.0$ & $6.0 \pm 5.0 / 3.0$ & $4.5-7.5$ & $p<0.05$ \\
\hline 40 & $62.0 \pm 22.2 / 13.0$ & $78.0 \pm 34.0 / 19.4$ & $33.0 \pm 8.0 / 4.3$ & $11.1 \pm 2.0 / 1.1$ & $7.1-17.4$ & $p<0.05$ \\
\hline 80 & $121.0 \pm 61.0 / 35.0$ & $179.0 \pm 82.0 / 47.3$ & $44.0 \pm 12.2 / 7.1$ & $21.0 \pm 22.0 / 13.0$ & $16.3-27.1$ & $p<0.05$ \\
\hline
\end{tabular}

$\mathrm{SD}^{\mathrm{a}}=$ standard deviation

$\mathrm{SE}^{\mathrm{b}}=$ standard error

C.I. ${ }^{\mathrm{c}}=$ confidence interval

*The effect of oil on $S$. hasta larvae $\mathrm{LC}_{50}$ was significant $(p<0.05)$ as determined by the General Linear Model (GLM) 
The TPH concentrations in CEWAF were 5.1, 17.7, 33.2 mg. $\mathrm{l}^{-1}$ after Slickgone ${ }^{\circledR}$ NS, Corexit ${ }^{\circledR}$ 9527, and Corexit $^{\circledR} 9500$ treatment, respectively. Whereas, the $\mathrm{KCO}$ alone at $1.0 \mathrm{~g}$. $\mathrm{l}^{-1}$ oil loading resulted in $2.0 \mathrm{mg}$. $1^{-1} \mathrm{TPH}$ in WAF, which was comparable to the previous analysis. Therefore, in determining the toxicity of oil, it is vital to consider the oil-water ratio, which means in a spill scenario, the spread of oil over the water will be an essential consideration in determining the risk to water column organisms. During exposure to KCO WAF from 0 to $96 \mathrm{hrs}$, increased mortality in $S$. hasta larvae was observed compared to control, which are in line with [1]. Similar experimental observations were reported by (34) as they observed high mortality rates upon exposure of gilthead sea bream (Sparus aurata) larval stages to Iraq oil water-soluble fraction (WSF) which reflect similar pollutant (KCO WAF/ CEWAF) and polluted (sea bream) treatment conditions applied in this study. Black sea bream (A. schlegeli) and red sea bream ( $P$. major) larvae exhibited similar results achieved in this study as their survival rate was significantly reduced upon exposure to WSF of KCO [36].

[1] have used approximately similar oil loadings $\left(1.2 \mathrm{~g} . ~^{1^{-1}}\right)$ to the one used in this study and observed an array of toxicological defects in Atlantic haddock (Melanogrammus aeglefinus) embryo-larval stages like cardiotoxicity, spinal deformities, and pericardial edema. More so, comparing the $\mathrm{LC}_{50}$ of WAF prepared at $1 \mathrm{~g} . \mathrm{1}^{-1}$ seawater with WAF prepared at higher loading (20 g. $1^{-1}$ seawater). A possible explanation is that partitioning of $\mathrm{KCO}$ in the aqueous phase was not increased, possibly because of the fixed surface area of the underlying seawater in the WAF preparation bottles and the slow stirring speed used [8] have determined that crude oil had evident effects on the larvae of various carp species, including the common carp (Cyprinus Carpio), carassin carp (C. auratus), and the grass carp (C. idella). It has been determined that oil toxicity is related to the aromatic fraction of low molecular weight (LMW) and high molecular weight (HMW) of polycyclic aromatic hydrocarbons (PAHs) [78]. Others have contributed

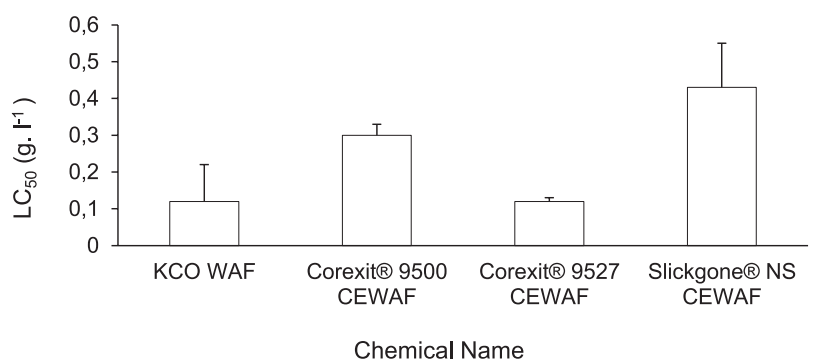

Fig. 4. Mean LC50 (g. $1^{-1}$ ) for S. hasta after exposure to the wateraccommodated fraction of Kuwait crude oil (KCO WAF) and chemically enhanced water-accommodated fraction (CEWAF) of three oil dispersantsas which are Corexit ${ }^{\circledR}$ 9500, Corexit ${ }^{\circledR}$ 9527, and Slickgone ${ }^{\circledR}$ NS. Error bars are standard deviations.

oil toxicity to yolk-sac larvae to their sensitivity to low total polyaromatic hydrocarbons (TPAH) [79, 80]. [81] Have concluded that exposure of embryonic stages of Atlantic cod (Gadus morhua) fish to oil can lead to larval mortality and morphological deformities. Exposure during the embryonic period (pre-hatch) of haddock larvae (Melanogrammus aeglefinus) resulted in reduced eye size and increased incidence of abnormal eye morphology, also oil-exposed fish had reduced mean blood flow speed, flow rate, and flow pulsatility $[82,83]$. Also, dispersion of oil droplets can contribute to the toxicity of the exposure medium as the droplets can behave like a reservoir for toxic components which can be harmful to fish health.

Like WAF alone, the toxicity of CEWAF also increased with exposure time (Table 3, Fig. 4). At $96 \mathrm{hrs}$, the $\mathrm{LC}_{50}$ values revealed that Corexit 9527 CEWAF exerted similar toxicity as observed with WAF alone, whereas Corexit@9500 CEWAF was slightly less toxic as its $\mathrm{LC}_{50}$ increased to $0.3 \pm 0.03$ from $0.12 \pm 0.1$ observed with WAF alone. CEWAF prepared by Slickgone treatment was the least toxic among all the dispersant tested, showing $\mathrm{LC}_{50} 0.43 \pm 0.12$ (C.I. 0.34$0.54)$.

The toxic effects of CEWAF mixtures on larval $S$. hasta were variable. A qualitative comparison between

Table 3. Showing different toxicity levels of Kuwait crude oil water-accommodated fraction (KCO WAF), and three chemically enhanced water accommodated fraction (CEWAF) of oil dispersants (Corexit ${ }^{\circledR} 9500$ CEWAF, Corexit ${ }^{\circledR} 9527$ CEWAF, and Slickgone ${ }^{\circledR}$ NS CEWAF) (g. $\left.\mathrm{l}^{-1}\right)$ on $S$. hasta larval survival from 24 to $96 \mathrm{hrs,} \mathrm{which} \mathrm{was} \mathrm{significant}(p<0.05)$ and as determined by the lethal concentrations which affects $50 \%$ of exposed larvae $\left(\mathrm{LC}_{50}\right)\left(\mathrm{g}\right.$. $\left.1^{-1}\right)$ for WAF and CEWAF's of $(\mathrm{KCO})$.

\begin{tabular}{|c|c|c|c|c|c|c|}
\hline Oil loadings (g. $\left.1^{-1}\right)$ & $\begin{array}{c}\mathrm{LC}_{50}\left(\mathrm{~g} . \mathrm{l}^{-1}\right) \\
24 \mathrm{hrs} \pm \mathrm{SD}^{\mathrm{a}} / \mathrm{SE}^{\mathrm{b}}\end{array}$ & $\begin{array}{c}\mathrm{LC}_{50}\left(\mathrm{~g} . \mathrm{l}^{-1}\right) \\
48 \mathrm{hrs} \pm \mathrm{SD} / \mathrm{SE}\end{array}$ & $\begin{array}{c}\mathrm{LC}_{50}\left(\mathrm{~g} . \mathrm{l}^{-1}\right) \\
72 \mathrm{hrs} \pm \mathrm{SD} / \mathrm{SE}\end{array}$ & $\begin{array}{c}\mathrm{LC}_{50}\left(\mathrm{~g} . \mathrm{l}^{-1}\right) \\
96 \mathrm{hrs} \pm \mathrm{SD} / \mathrm{SE}\end{array}$ & $\begin{array}{c}96 \mathrm{hrs} \\
95 \% \text { C.I. }^{\mathrm{c}}\end{array}$ & $p$ \\
\hline KCO WAF & $58.0 \pm 103.0 / 34.3$ & $2.0 \pm 2.0 / 1.0$ & $0.4 \pm 0.1 / 0.02$ & $0.12 \pm 0.1 / 0.03$ & $0.1-0.2$ & $p<0.05$ \\
\hline Corexit $^{\circledR} 9500$ CEWAF & $4.12 \pm 2.0 / 10.0$ & $0.9 \pm 0.13 / 0.07$ & $0.7 \pm 0.13 / 0.07$ & $0.3 \pm 0.03 / 0.02$ & $0.207-0.410$ & $p<0.05$ \\
\hline Corexit $^{\circledR} 9527$ CEWAF & $0.4 \pm 0.01 / 0.007$ & $0.2 \pm 0.05 / 0.03$ & $0.2 \pm 0.01 / 0.004$ & $0.12 \pm 0.01 / 0.006$ & $0.107-0.136$ & $p<0.05$ \\
\hline Slickgone ${ }^{\circledR}$ NS CEWAF & $1.0 \pm 0.0 / 0.0$ & $1.0 \pm 0.1 / 0.05$ & $0.63 \pm 0.05 / 0.03$ & $0.43 \pm 0.12 / 0.07$ & $0.341-0.538$ & $p<0.05$ \\
\hline
\end{tabular}

$\mathrm{SD}^{\mathrm{a}}=$ standard deviation

$\mathrm{SE}^{\mathrm{b}}=$ standard error

C.I. ${ }^{\mathrm{c}}=$ confidence interval 
all $\mathrm{LC}_{50} \mathrm{~s}$ for CEWAF test chemicals and WAF of KCO was performed. The overall toxicity pattern of the CEWAF solutions compared to that of $\mathrm{KCO}$ against sea bream pre-hatched larvae was: KCO WAF was similarly toxic to Corexit ${ }^{\circledR} 9527$ CEWAF, followed by Corexit ${ }^{\circledR}$ 9500 CEWAF, then Slickgone ${ }^{\circledR}$ NS CEWAF as the least toxic test chemical to fish larval stages. It was clear that in the case of Corexit ${ }^{\circ} 9527$ CEWAF, it exhibited similar toxicity to $\mathrm{KCO}$, and the addition of dispersant did not enhance the dissolution of oil into the aqueous medium, although Corexit ${ }^{\circledR} 9527$ CEWAF had a higher TPH concentration than KCO WAF did. Laboratory investigations have indicated that oil response agents (dispersants) increase parent oil toxicity through the process of increasing the solubility of PAHs in the water column $[64,76]$.

The change in the order of toxicity of CEWAF mixtures may be related to the different degradation rates and degradation products of the dispersant, indicating that toxicity data vary for different oil dispersants and different crude oil types [84]. [44] Demonstrated that the primary function of oil spill dispersant was to increase the entry of oil into the water column, thus modifying the exposure medium and increasing its toxicity. Dispersion of crude oil with oil dispersant (CEWAF) has in some cases increased its toxicity compared to the toxicity of KCO WAF, as dispersants solubilized more of the oil fraction in the water column, thus, the oil will become more bioavailable to fish larvae [85]. [86] Observed that exposure of chinook salmon smolts (Onchorhyncus tshawytscha) to Prudhoe Bay crude oil (PBCO) WAF and Corexit ${ }^{\circledR} 9500$ CEWAF resulted in $\mathrm{LC}_{50}$ of $155.93 \mathrm{mg}^{-1}$, for Corexit ${ }^{\circledR} 9500 \mathrm{CEWAF}$ was some 20 times higher (i.e., less toxic) than that of the $\mathrm{LC}_{50}$ WAF of PBCO (7.46 mg. $\left.\mathrm{l}^{-1}\right)$. This result suggests that hydrocarbon bioavailability to smolts may have been reduced under dispersed conditions and may be attributed to several factors. [84] also, observed an increase in larval mortality of crimson-spotted rainbow fish (Melanotaenia fluviatilis) with time in a $96 \mathrm{hrs}$ exposure period to crude oil WAF and CEWAF. [43] Observed that dispersed oil was more toxic to fish early life stages than native oil did.

[21] observed that larvae are not able to avoid waters contaminated with oil and dispersed oil as chemical receptors might have been damaged at the initial interaction with petroleum hydrocarbons. [87] indicated that Corexit $\AA 9500$ and 9527 dispersants are of low to moderate toxicities when tested on most aquatic species. Many factors may contribute to the test results variability, such as species and exposure duration. This finding is in agreement with what was obtained for larval $S$. hasta in a way that KCO WAF of similar toxicity to Corexit ${ }^{\circledR} 9527$ CEWAF and Corexit ${ }^{\circledR} 9500$ CEWAF was less toxic. [66] had observed that when Corexit ${ }^{\circledR}$ 9500A was mixed with South Louisiana sweet crude oil produced similar toxicity to other types of dispersants. Those findings are in agreement with data reported by [88] in which they observed that petroleum hydrocarbon products, which did not undergo complete dissolution in the aqueous phase, but when dispersed; adversely affected marine organisms because of the joint-effect of toxicity and physical fouling. [89] have indicated that both Corexit ${ }^{\circledR}$ 9500A and 9527 chemical dispersant formulations did not exhibit a difference in terms of its toxicity against the marine organism. However, in a study performed by [90], they observed that dispersed oil exerted higher toxicity than undispersed oil in early-life stages of orangespotted grouper Epinephelus coioide. More arguably, the acute toxic effect concentration for Corexit 9500 dispersant on biological species has a wide range, and [87] concluded that it can be $<1$ to $>1000 \mathrm{mg}^{-1}$. Moreover, [91] have indicated that it can range from 23 to $50 \mathrm{mg}^{-1}$ against multiple marine species from the Gulf of Mexico. It's important to highlight the global differences in toxicity data amongst multiple marine trophic levels concerning oil and oil spill response agents (dispersants) because of the variability of analytical methods and biological species tested [11].

Acute toxicity data obtained from the current study will add further understanding to the global database for the toxicity of oil and oil spill-response agents, and by investigating the toxicity of dispersed and undispersed oil on $S$. hasta will unquestionably increase taxa diversity for marine ecosystems in regions of similar nature to the ones that Sobaity Sea bream thrive in. Still the decision of using or not using oil dispersants as an oil spill response (OSR) strategy is questionable and depends on the timing and location of the spill incident considering that there will always be trade-offs to this choice to assess the ecological benefits or harms associated with dispersant applications [92, 93].

Although the outcomes of this study exhibit similar toxicity of dispersed oil to that of parent oil, the applications of oil response agents remain a controversial issue that requires constant scientific review and assessment. Also, approving dispersant use should be individually evaluated as each oil spill event (scenario) represents a different system of mixed physical, chemical, and biological entities. There is a paucity of toxicity data regarding selected marine fish species in different regions of the world that can be susceptible to major oil spills; therefore additional ecotoxicological research is required on the acute toxicity of oil spill response agents on economically important fisheries resources to assist in proper management local resources.

\section{Conclusions and Recommendations}

In the present study, the toxicity of dispersed and undispersed crude oil was investigated against the larval stage of sobaity sea bream $S$. hasta using field relevant experimental durations and concentrations of test chemicals. Based on the results of fish toxicity 
tests using different chemical treatments, the following conclusions have been drawn:

1. In the experiments of this study, it was observed that $1 \mathrm{~g}$. $\mathrm{l}^{-1}$ seawater loading was most suitable for WAF preparation because, upon dispersant treatment, the KCO CEWAF was turbid at higher concentrations of oil loadings making it challenging to use in toxicity assay, especially when attempting to count exposed larvae as they are not visible under the turbid solution.

2. It was observed that individual dispersants had a different capacity in dispersing crude oil as represented by TPH values along with that of crude oil alone.

3. The toxicity of dispersed and undispersed oil on the larval stage of $S$. hasta was variable, demonstrating the different dispersion ability of oil dispersants to disperse oil in the aqueous medium.

4. Future research is required to understand the effects of other types of oil dispersants on the early life stages as well as adult stages of commercially important marine fish species.

5. Long-term effects of dispersed and undispersed oil should be thoroughly assessed concerning other commercially important fish species.

\section{Acknowledgments}

We would like to thank the Kuwait Institute for Scientific Research and Newcastle University for providing facilities to carry out this research.

\section{Conflict of Interest}

The authors declare no conflict of interest.

\section{References}

1. SØRHUS E., EDVARDSEN R.B., KARLSEN Ø., NORDTUG T., VAN DER MEEREN T., THORSEN A., HARMAN C., JENTOFT S., MEIER S. Unexpected interaction with dispersed crude oil droplets drives severe toxicity in Atlantic haddock embryos. PloS one. 10 (4), e0124376, 2015.

2. STODDART M.C.J., BURT B.Q. Energy justice and offshore oil: Weighing environmental risk and privilege in the north Atlantic. Environ. Sociol. ahead-of-print, 1-13, 2020.

3. FRITT-RASMUSSEN J., WEGEBERG S., GUSTAVSON K., SØRHEIM K.R., DALING P.S., JØRGENSEN K., TONTERI O. HOLST-ANDERSEN, J.P. Heavy fuel oil (HFO): A review of fate and behaviour of HFO spills in cold seawater, including biodegradation, environmental effects and oil spill response. Nordic Council of Ministers, 2018.

4. LEWIS A., DALING P. Oil spill dispersants. guidelines on the planning and effective use of oil spill dispersants to minimize the effects of oil spills. SINTEF, Trondheim, 2001.
5. HJERMANN D.Ø., MELSOM A., DINGSØR G.E., DURANT J.M., EIKESET A.M., RØED L.P., OTTERSEN G., STORVIK G., STENSETH N.C. Fish and oil in the Lofoten-Barents sea system: Synoptic review of the effect of oil spills on fish populations. Mar. Ecol. Prog. Ser. 339, 283, 2007.

6. BLANCHARD A., HAUGE K.H., ANDERSEN G., FOSSA J.H., GRØSVIK B.E., HANDEGARD N.O., KAISER M., MEIER S., OLSEN E., VIKEBØ F. Harmful routines? uncertainty in science and conflicting views on routine petroleum operations in Norway. Mar. Policy. 43, 313, 2014.

7. ZHILNIKOVA N.A., MATELENOK I.V., SMIRNOVA A.S., SMIRNOVA V.O.. Special aspects of modeling on accidental oil spills in inland sea waters. IOP conference series. Materials Science and Engineering; 537, 62013, 2019.

8. RASHEED R.O., Evaluation of heavy metals and polyaromatic hydrocarbons in water, fish, and sediments within Derbendikhan Reservoir, Ph.D. Thesis, Univ. of Sulaimani, Sulaimani, Iraq., 138, 2008.

9. BEJARANO A.C., GARDINER W.W., BARRON M.G., WORD J.Q. Relative sensitivity of arctic species to physically and chemically dispersed oil determined from three hydrocarbon measures of aquatic toxicity. Mar. Pollut. Bull . 122, 316-322, 2017.

10. 10. BARRON, M.G., CHIASSON, S.C., BEJARANO, A.C. Ecotoxicology of Deep Ocean Spills. In: Murawski S. et al. (ed). Springer, Cham. 2020.

11. BARRON M.G., BEJARANO A.C., CONMY R.N., SUNDARAVADIVELU D., MEYER P. Toxicity of oil spill response agents and crude oils to five aquatic test species. Mar. Pollut. Bull. 153, 110954, 2020.

12. LI Y., HU C., QUIGG A., GAO H. Potential influence of the deepwater horizon oil spill on phytoplankton primary productivity in the northern gulf of mexico. Environ. Res. Lett. 14, 094018, 2019.

13. ISSA N., VEMPATTI S. Oil spills in the arabian gulf: A case study and environmental review. Environ. Nat. Resour. 8, 144, 2018.

14. MARZOOQ H., NASER H.A., ELKANZI E. M. Quantifying exposure levels of coastal facilities to oil spills in Bahrain, Arabian gulf. Environ. Monit. Assess. 191, 1, 2019.

15. CENTRE NATIONAL POUR L'EXPLOITATION DES OCEANS. Fate and Effect of Oil Spill. November 1979, CENTRE NATIONAL POUR L'EXPLOITATION DES OCEANS, Paris, 1981.

16. KOCAN R.M., HOSE J.E., BAKER T.T., BROWN E.D. Pacific herring (Clupea pallasi) embryo sensitivity to prudhoe bay petroleum hydrocarbons: Laboratory evaluation and in situ exposure at oiled and unoiled sites in prince William sound. Can. J. Fish. Aquat. Sci. 53, 23662375, 1996.

17. MARTY G.D., OKIHIRO M.S., HINTON D.E. Fish histopathology damage assessment after the. Alaska Department of Fish and Game, Habitat and Restoration Division, Anchorage, Alaska., USA: Citeseer, 2000.

18. WANG Z., FINGAS M. Study of the effects of weathering on the chemical composition of a light crude oil using $\mathrm{GC} /$ MS GC/FID. J. Microcolumn Sep. 7 (6), 61, 1995.

19. LI M., GARRETT C. The relationship between oil droplet size and upper ocean turbulence. Mar. Pollut. Bull. 36, 961, 1998.

20. LESSARD R.R., DEMARCO G. The significance of oil spill dispersants. Spill Sci. Technol. Bull. 6, 59, 2000. 
21. FARID W.A., AL-SALMAN A.N., HAMMAD D.S., ALSAAD H.T., SALIH S.M., ALHELLO A.Z. Toxic effects of dissolved and dispersed crude oils on eggs and larvae of some fishes from shatt al-arab river. J. Pharm. Chem. Biol. Sci. 6, 88, 2016.

22. OTITOLOJU A.A. Crude oil plus dispersant: Always a boon or bane? Ecotoxicol. Environ. Saf. 60, 198, 2005.

23. VENOSA A.D., HOLDER E.L. Biodegradability of dispersed crude oil at two different temperatures. Mar. Pollut. Bull. 54, 545, 2007.

24. NYMAN J.A., KLERKS P.L., BHATTACHARYYA S. Effects of chemical additives on hydrocarbon disappearance and biodegradation in freshwater marsh microcosms. Environ Pollut. 149, 227, 2007.

25. OLIVARES-RUBIO H.F., ESPINOSA-AGUIRRE J.J. Acetylcholinesterase activity in fish species exposed to crude oil hydrocarbons: A review and new perspectives. Chemosphere. 249, 128401, 2020.

26. THERON M., MARZIOU A., PICHAVANT-RAFINI K., LE FLOCH S., LEMAIRE P., DUSSAUZE M. Combined effects of high hydrostatic pressure and dispersed oil on the metabolism and the mortality of turbot hepatocytes (scophthalmus maximus). Chemosphere, 249, 126420, 2020.

27. KHURSIGARA A.J., JOHANSEN J.L., ESBAUGH A.J. The effects of acute crude oil exposure on growth and competition in red drum, sciaenops ocellatus. Sci. Total Environ. 751, 141804, 2021.

28. LUNEL T-The Braer Spill: Oil fate governed by dispersion. Proceedings of the International Oil Spill Conference, American Petroleum Institute. 1995 (1), 955, 1995.

29. CRONE T., TOLSTOY M. Magnitude of the 2010 gulf of mexico oil leak. Science. 330, 63, 2010.

30. ROSENBAUER R.J., CAMPBELL P.L., LAM A., LORENSON T.D., HOSTETTLER F.D., THOMAS B., WONG F.L. Reconnaissance of Macondo-1 well oil in sediment and tarballs from the northern Gulf of Mexico shoreline, Texas to Florida. U. S. Geological Survey, 2010.

31. KUJAWINSKI E.B., KIDO SOULE M.C., VALENTINE D.L., BOYSEN A.K., LONGNECKER K., REDMOND M.C. Fate of dispersants associated with the deepwater horizon oil spill. Environ. Sci. Technol. 45, 1298, 2011.

32. MCNUTT M.K., CUE S., LUBCHENCO J., HUNTER T, DREYFUS G., MURAWSKI S.A., KENNEDY D.M. Applications of science and engineering to quantify and control the deepwater horizon oil spill. Proceedings of the National Academy of Sciences - PNAS. 109: 20222, 2012.

33. FRASIER K.E., SOLSONA-BERGA A., STOKES L., HILDEBRAND J.A. Impacts of the Deepwater Horizon Oil Spill on Marine Mammals and Sea Turtles. In: Deep Oil Spills. Springer, 431, 2020.

34. WISE C.F., WISE J.T., WISE S.S., THOMPSON W.D., WISE JR. J.P., WISE SR. J.P. Chemical dispersants used in the gulf of mexico oil crisis are cytotoxic and genotoxic to sperm whale skin cells. Aquat. Toxicol. 152, 335, 2014.

35. GLAMUZINA B., TUDOR M., KATAVIÉ I. The effects of the water soluble fraction of iraq crude oil on eggs, larvae and postlarvae of gilthead sea bream, Sparus aurata linnaeus 1758. Oil Chem. Pollut. 7, 283, 1990.

36. CHANG Y., LEE K., KANG D., CHIN P. Effects of the water soluble fraction from Kuwait crude oil on the early larval stages of three cultured fish species. J. Aquaculture. 13, 69, 2000.

37. ERIEGHA O., OMITOYIN B., AJANI E. Evaluation of haematological and biochemical parameters of juvenile oreochromis niloticus after exposure to water soluble fractions of crude oil. J. Appl. Sci. Environ. Manage. 21, 1041, 2017.

38. AJAH P.O., UKUTT E.R. The effect of water soluble fraction of crude oil on the biochemical, hematological and enzymological changes in fed and starved clariidae catfish juveniles. Int. J. Eng. Res. 9,1386, 2018.

39. FAKOLUJO O.I., ADEWOLE H.A., OBUOTOR E.M., OLALEYE V.F. Growth performance and selected biochemical indices assessment in the serum and liver of clarias LARIA gariepinus juveniles exposed to varying concentrations of water-soluble fraction of crude oil. Borneo Science. 39, 2018.

40. KHOSHBAVAR ROSTAM H.A., YELGHI S. Acute toxicity and hematological indices and biochemical parameters of giant sturgeon, huso huso after acute exposure to crude oil. Iran J Fish Sci . 19, 1292, 2020.

41. SANDRINI-NETO L, GERAUDIE P, SANTANA MS, CAMUS L. Effects of dispersed oil exposure on biomarker responses and growth in juvenile wolfish Anarhichas denticulatus. Environ. Sci. Pollut. Res. 23, 21441, 2016.

42. THERON M., MARZIOU A., PICHAVANT-RAFINI K., LE FLOCH S., LEMAIRE P., DUSSAUZE M. Combined effects of high hydrostatic pressure and dispersed oil on the metabolism and the mortality of turbot hepatocytes (Scophthalmus maximus). Chemosphere 249, 126420, 2020.

43. JOHANN S., NÜßER L., GOßEN M., HOLLERT H., SEILER T.B. Differences in biomarker and behavioral responses to native and chemically dispersed crude and refined fossil oils in zebrafish early life stages. Sci. Total Environ. 709, 136174, 2020.

44. SINGER M.M., AURAND D., BRAGIN G.E., CLARK J.R., COELHO G.M., SOWBY M.L., TJEERDEMA, R.S. Standardization of the preparation and quantitation of water-accommodated fractions of petroleum for toxicity testing. Mar. Pollut. Bull. 40, 1007, 2000.

45. TORFI MOZANZADEH M., YAGHOUBI M., YAVARI V., AGH N., MARAMMAZI J.G., TOPIC POPOVIC N. Reference intervals for haematological and plasma biochemical parameters in sobaity sea bream juveniles (Sparidentex hasta, valenciennes 1830). Comp. Clin. Path. 24, 1501, 2015.

46. SHALES S.- Biological and ecological effects of oils. . In: GREEN J. TM (ed). The Fate and Effects of Oil in Freshwater. London and New York: British Petroleum Co. and Elseveir Applied Science. 81, 1989.

47. NORCROSS B.L., MUTER F., HOLLADAY B.A. Habitat models for juvenile pleuronectids around Kodiak island, Alaska. Fish. Bull. 95, 504, 1997.

48. MCGURK M.D., BROWN E.D. Egg larval mortality of pacific herring in prince william sound, alaska, after the exxon valdez oil spill. Can. J. Fish. Aquat. Sci. 53, 2343, 1996.

49. HEINTZ R., RICE S., WERTHEIMER A., BRADSHAW R.F., THROWER F.P., JOYCE J.E., SHORT J.W. Delayed effects on growth and marine survival of pink salmon Oncorhynchus gorbuscha after exposure to crude oil during embryonic development. Mar. Ecol. Prog. Ser. (Halstenbek). 208, 205, 2000.

50. LAMMER E., KAMP H.G., HISGEN V., KOCH M., REINHARD D., SALINAS E.R., WENDLER K., ZOK S., BRAUNBECK T. Development of a flow-through system for the fish embryo toxicity test (FET) with the zebrafish (Danio rerio). Toxicol. in Vitro. 23, 1436, 2009.

51. MUHLING B.A., ROFFER M.A., LAMKIN J.T., INGRAM JR. G.W., UPTON M.A., GAWLIKOWSKI G., 
MULLER-KARGER F., HABTES S., RICHARDS W.J. Overlap between atlantic bluefin tuna spawning grounds and observed deepwater horizon surface oil in the northern gulf of mexico. Mar. Pollut. Bull. 64, 679-687, 2012.

52. SØRHUS E., INCARDONA J.P., FURMANEK T., GOETZ G.W., SCHOLZ N.L., MEIER S., ET AL. EDVARDSEN, R.B., JENTOFT, S. Novel adverse outcome pathways revealed by chemical genetics in a developing marine fish. eLife. 6, 20707, 2017.

53. LIE K.K., MEIER S., SØRHUS E., EDVARDSEN R.B., KARLSEN Ø., OLSVIK P.A. Offshore crude oil disrupts retinoid signaling and eye development in larval atlantic haddock. Front. Mar. Sci. 6, 368, 2019.

54. KARAM Q.E. Toxicity of Kuwait crude oil and dispersed oil on selected marine fish species of Kuwait $[\mathrm{PhD}$ dissertation]. Newcastle University, 2011.

55. KARAM Q., ALI M., SUBRAHMANYAM M.N.V., AL-ABDUL ELAH K., BENTLEY M., BEG M.U. A comparative study on the effect of dispersed and undispersed kuwait crude oil on egg hatching and larval survival of Epinephelus coioides. J. Environ. Biol . 40, 192, 2019.

56. REGIONAL ORGANIZATION FOR THE PROTECTION OF MARINE ENVIRONMENT (ROPME). Manual of Oceanographic Observations and Pollutant Analysis Methods. 1st ed. Kuwait, 1999.

57. AL-ABDUL-ELAH K.M. Procedures and problems of marine fish hatcheries with special reference to Kuwait [dissertation]. University of Sterling, 1984.

58. TENG S., EL-ZAHR C., AL-ABDUL-ELAH K., ALMATAR S. Pilot-scale spawning and fry production of blue-fin porgy, Sparidentex hasta (valenciennes), in Kuwait. Aquaculture. 178, 27, 1999.

59. ORGANISATION FOR ECONOMIC CO-OPERATION AND DEVELOPMENT (OECD). Fish Embryo Toxicity (FET) Test. OECD Guideline for the testing of chemicals, 2006.

60. BOARD, OCEAN STUDIES., NATIONAL RESEARCH COUNCIL. Oil Spill Dispersants: Efficacy and Effects. National Academies Press, 2005.

61. BEJARANO A.C. Critical review and analysis of aquatic toxicity data on oil spill dispersants. Environ. Toxicol. Chem. 37, 2989, 2018.

62. USEPA. NCP Subpart J Technical Notebook a Compendium to the NCP Product Schedule. U.S. Environmental Protection Agency, 2019.

63. HILL A.J., TERAOKA H., HEIDEMAN W., PETERSON R.E. Zebrafish as a model vertebrate for investigating chemical toxicity. Toxicol. Sci. 86, 6-19, 2005.

64. PHILIBERT D.A., LYONS D., PHILIBERT C., TIERNEY K.B. Field-collected crude oil, weathered oil and dispersants differentially affect the early life stages of freshwater and saltwater fishes. Sci. Total Environ. 647, 1148, 2019

65. KOYAMA J., KAKUNO A. Toxicity of heavy fuel oil, dispersant, and oil-dispersant mixtures to a marine fish, pagrus major. Fish. Sci. 70, 587-594, 2004.

66. HEMMER M.J., BARRON M.G., GREENE R.M. Comparative toxicity of eight oil dispersants, louisiana sweet crude oil (LSC), and chemically dispersed LSC to two aquatic test species. Environ. Toxicol. Chem. 30, 2244, 2011.

67. VIKEBØ F.B., RØNNINGEN P., LIEN V.S., MEIER S., REED M., ÅDLANDSVIK B., KRISTIANSEN T. Spatiotemporal overlap of oil spills and early life stages of fish. ICES J. Mar. Sci. 71, 970, 2014.
68. MARTÍNEZ-JERÓNIMO F., VILLASEÑOR R., RÍOS G., ESPINOSA-CHAVEZ F. Toxicity of the crude oil watersoluble fraction and kaolin-adsorbed crude oil on Daphnia magna (crustacea: Anomopoda). Arch. Environ. Contam. Toxicol. 48, 444, 2005.

69. PEREIRA T.M., MERÇON J., PASSOS L.S., COPPO G.C., LOPES T.O.M., CABRAL D.S., SCHERER R., CHIPPARI-GOMES A.R. Effects of the water-soluble fraction of diesel oil (WSD) on the fertilization and development of a sea urchin (echinometra lucunter). Ecotoxicol. Environ. Saf. 162, 59, 2018.

70. LIN F., OSACHOFF H.L., KENNEDY C.J. Physiological disturbances in juvenile sockeye salmon (Oncorhynchus nerka) exposed to the water-soluble fraction of diluted bitumen. Aquat. Toxicol. 220, 105383, 2020.

71. NAVAS J.M., BABÍN M., CASADO S., FERNÁNDEZ C., TARAZONA J.V. The prestige oil spill: A laboratory study about the toxicity of the water-soluble fraction of the fuel oil. Mar. Environ. Res. 62, Supplement 1, S352, 2006.

72. GONZÀLES-DONCEL M., GONZÀLES L. FERNÀNDEZ-TORIJA C. Toxic effects of an oil spill on fish early life stages may not be exclusively associated to PAHs: Studies with prestige oil and medaka Oryzias latipes. Aquat. Toxicol. 87, 280, 2008.

73. MILINKOVITCH T., KANAN R., THOMAS-GUYON H., LE FLOCH S.. Effects of dispersed oil exposure on the bioaccumulation of polycyclic aromatic hydrocarbons and the mortality of juvenile Liza ramada. Sci. Total Environ. 409, 1643, 2011.

74. BARRON M.G. Environmental contaminants altering behavior. In: G. DELL'OMO (ed). Behavioral Ecotoxicology. John Wiley \& Sons, Ltd, 167, 2002.

75. BARRON M.G., HEMMER M.J., JACKSON C.R. Development of aquatic toxicity benchmarks for oil products using species sensitivity distributions. Integr. Environ. Assess. Manag. 9, 610, 2013.

76. HODSON P. The toxicity to fish embryos of PAH in crude and refined oils. Arch. Environ. Contam. Toxicol. 73, 12, 2017.

77. STEFANSSON E.S., LANGDON C.J., PARGEE S.M., BLUNT S.M., GAGE S.J., STUBBLEFIELD W.A. Acute effects of non-weathered and weathered crude oil and dispersant associated with the deepwater horizon incident on the development of marine bivalve and echinoderm larvae. Environ. Toxicol. Chem. 35, 2016, 2016.

78. PERRICHON P., LE MENACH K., AKCHA F., CACHOT J., BUDZINSKI H., BUSTAMANTE P. Toxicity assessment of water-accommodated fractions from two different oils using a zebrafish (Danio rerio) embryo-larval bioassay with a multilevel approach. Sci. Total Environ. 568, 952, 2016.

79. CARLS M.G., RICE S.D., HOSE J.E. Sensitivity of fish embryos to weathered crude oil: Part I. low-level exposure during incubation causes malformations, genetic damage, and mortality in larval pacific herring (Clupea pallasi). Environ. Toxicol. Chem. 18, 481, 1999.

80. INCARDONA J.P., GARDNER L.D., LINBO T.L., BROWN T.L., ESBAUGH A.J., MAGER E.M., STIEGLITZ J.D., FRENCH B.L., LABENIA J.S., LAETZ C.A., TAGAL M. Deepwater horizon crude oil impacts the developing hearts of large predatory pelagic fish. Proceedings of the National Academy of Sciences. 2014.

81. HANSEN B.H., SALABERRIA I., READ K.E., WOLD P.A., HAMMER K.M., OLSEN A.J., ALTIN D., ØVERJORDET I.B., NORDTUG T., BARDAL T., KJØRSVIK E. Developmental effects in fish embryos 
exposed to oil dispersions - the impact of crude oil microdroplets. Mar. Environ. Res. 150, 104, 2019.

82. LIE K.K., MEIER S., SØRHUS E., EDVARDSEN R.B., KARLSEN Ø., OLSVIK P.A. Offshore crude oil disrupts retinoid signaling and eye development in larval atlantic haddock. Front. Mar. Sci. 6, 368, 2019.

83. GURUNG S., DUBANSKY B., VIRGEN C.A., VERBECK G.F., MURPHY D.W. Effects of crude oil vapors on the cardiovascular flow of embryonic gulf killifish. Sci. Total Environ. 751, 141627, 2021.

84. POLLINO, C.A., HOLDWAY, D.A. Toxicity testing of crude oil and related compounds using early life-stages of the crimson-spotted rainbow fish Melanotaenia fluviatilis. Ecotoxicol. Environ. Saf. 52, 180, 2002.

85. SINGER M.M., GEORGE S., LEE I., JACOBSON S., WEETMAN L.L., BLONDINA G., TJEERDEMA R.S., AURAND D., SOWBY M.L. Effects of dispersant treatment on the acute aquatic toxicity of petroleum hydrocarbons. Arch. Environ. Contam. Toxicol. 34, 177, 1998.

86. LIN C.Y, ANDERSON B.S., PHILLIPS B.M., PENG A.C., CLARK S., VOORHEES J., WU H.D.I., MARTIN M.J., MCCALL J., TODD C.R., HSIEH F. Characterization of the metabolic actions of crude versus dispersed oil in salmon smolts via NMR-based metabolomics. Aquat. Toxicol. 95, 230, 2009.

87. GEORGE-ARES A., CLARK J.R. Aquatic toxicity of two corexit dispersants. Chemosphere. 40, 897, 2000.
88. GIRLING A.E., MARKARIAN R.K., BENNETT D. Aquatic toxicity testing of oil products-some recommendations. Chemosphere. 24, 1469, 1992.

89. SINGER M.M., GEORGE S., JACOBSON S., LEE I., WEETMAN L.L., TJEERDEMA R.S., SOWBY M.L. Comparison of acute aquatic effects of the oil dispersant corexit 9500 with those of other corexit series dispersants. Ecotoxicol. Environ. Saf. 35, 183, 1996.

90. ECHOLS B.S., LANGDON C.J., STUBBLEFIELD W.A., RAND G.M., GARDINALI P.R. A comparative assessment of the aquatic toxicity of corexit 9500 to marine organisms. Arch. Environ. Contam. Toxicol. 77, 40, 2019.

91. LEWIS A., PRINCE R.C. Integrating dispersants in oil spill response in arctic and other icy environments. Environ. Sci. Technol. 52, 6098, 2018.

92. ARNBERG M., KEITEL-GRÖNER F., WESTERLUND S., RAMANAND S., BECHMANN R.K., BAUSSANT T. Exposure to chemically-dispersed oil is more harmful to early developmental stages of the northern shrimp pandalus borealis than mechanically-dispersed oil. Mar. Pollut. Bull. 145, 409, 2019.

93. CAMUS L., SMIT M.G.D. Environmental effects of arctic oil spills and spill response technologies, introduction to a 5 year joint industry effort. Mar. Environ. Res. 144, 250, 2019. 